\title{
Effect of Pretreatment on Hydraulic Performance of the Integrated Membrane Process for Concentrating Nutrient in Biogas Digestate from Swine Manure
}

\author{
Yuanhang Zhan ${ }^{1,2}{ }^{\mathbb{D}}$, Fubin Yin ${ }^{1}$, Caide Yue ${ }^{1}$, Jun Zhu ${ }^{2}{ }^{\oplus}$, Zhiping Zhu ${ }^{1}$, Mengyuan Zou ${ }^{1}$ and \\ Hongmin Dong ${ }^{1, *}$ \\ 1 Institute of Environment and Sustainable Development in Agriculture, \\ Chinese Academy of Agricultural Sciences, Beijing 100081, China; zzyh727@126.com (Y.Z.); \\ carft_257@163.com (F.Y.); ycdhope@163.com (C.Y.); zhuzhiping@caas.cn (Z.Z.); condor1228@sina.cn (M.Z.) \\ 2 Department of Biological and Agricultural Engineering, University of Arkansas, \\ Fayetteville, AR 72701, USA; junzhu@uark.edu \\ * Correspondence: donghongmin@caas.cn; Tel.: +86-108-210-9979
}

Received: 24 August 2020; Accepted: 14 September 2020; Published: 23 September 2020

\begin{abstract}
Nanofiltration (NF) or reverse osmosis (RO) process has been widely applied for concentrating nutrient in biogas digestate. However, efficient pretreatment is key to the sustainable operation of NF or RO. In this study, the combination of NF and RO for concentrating biogas digestate was compared using different pretreatments of hollow fiber ultrafiltration membrane (HFUFM) and ceramic membrane (CUFM). Pilot-scale batch tests were conducted (500 L). CUFM showed a higher membrane flux than HFUFM $\left(100 \sim 180 \mathrm{~L} \cdot\left(\mathrm{m}^{2} \cdot \mathrm{h}\right)^{-1}\right.$ vs. $\left.17 \sim 35 \mathrm{~L} \cdot\left(\mathrm{m}^{2} \cdot \mathrm{h}\right)^{-1}\right)$, but they showed little impact on the NF + RO process. Membrane fluxes of NF and RO were 20 48 $\mathrm{L} \cdot\left(\mathrm{m}^{2} \cdot \mathrm{h}\right)^{-1}$ and $16 \sim 40 \mathrm{~L} \cdot\left(\mathrm{m}^{2} \cdot \mathrm{h}\right)^{-1}$, respectively. In the RO permeates, the removal rates of total suspended solids (TSS), total solids (TS), chemical oxygen demand (COD), total nitrogen (TN), $\mathrm{NH}_{4}{ }^{+}-\mathrm{N}$, and $\mathrm{Cl}^{-}$were above $91 \%$. In the concentrates, TN and total potassium (TK) were concentrated by 1.60 and 2.00 folds in the NF stage, and by 2.10 and 2.30 folds in the RO stage. Further attention should be paid to the antibiotics risks in the concentrates before they are utilized as plant fertilizers.
\end{abstract}

Keywords: pretreatment; $\mathrm{NF}+\mathrm{RO}$; permeate; concentrate; biogas digestate

\section{Introduction}

Anaerobic digestion (AD) is a useful technology to treat swine manure [1], which generates biogas as a green energy but a large volume of digestate at the same time [2]. The digestate is rich in nitrogen, phosphorus, potassium, amino acid, and other biologically active substances [3-5], which can be utilized as organic fertilizer [6] to improve plant growth and quality [7]. However, the large volume of digestate could exceed the soil receiving capacity by irrigation $[3,8]$, direct discharge to crop field will pose a high pollution risk to the environment due to runoff and seepage $[4,6]$. Thus, it is imperative to effectively treat the large amount of biogas digestate before discharging.

Membrane separation technology has been widely used in industrial processes [9-13]. It has also been employed as a new process for the high-quality processing of biogas digestate [8,14-16]. The membrane separation technologies used in biogas digestate treatment include microfiltration membrane (MF), ultrafiltration membrane (UF), nanofiltration membrane (NF), and reverse osmosis (RO). Among them, MF and UF are commonly used as pretreatment for NF and RO, a common practice for further concentration of nutrients $[16,17]$. Previous studies showed that clean permeates could be obtained for recycling by the NF and RO processes $[8,18,19]$, and the concentrates with concentrated nutrients and reduced volume could be obtained as a valuable organic fertilizer [18,20-22]. 
Additionally, studies showed that the combined process of NF and RO (NF + RO) had lower energy consumption and better nutrient concentration performance than the single process, either NF or $\mathrm{RO}[23]$.

However, since the biogas digestate contained a large amount of suspended solids and organic matter [8,24-26], which could cause membrane blockage during the NF or RO concentration process [27-29], effective physical pretreatments of the digestates are required. The working efficiency of the NF or $\mathrm{RO}$ process could be significantly improved with membrane pretreatment $[2,8,20]$. The common fouling-resistant membrane materials for pretreatment include inorganic ceramic membrane (CUFM) and organic hollow fiber ultrafiltration membrane (HFUFM).

CUFM and HFUFM have been reported as pretreatment of biogas digestate or swine manure wastewater in many studies. Zacharof (2014) [30] tested a ceramic microfiltration membrane with a pore size of $200 \mathrm{~nm}$ to pretreat the biogas digestate from a swine farm, the results showed that the membrane system was capable of processing up to $140 \mathrm{~L} \cdot\left(\mathrm{m}^{2} \cdot \mathrm{h}\right)^{-1}$ volume, reducing by $20.75 \%$ total solids and by $48.58 \%$ coarse particles. Pieters et al. (1999) [31] applied ceramic membrane with a pore size of $0.1 \mu \mathrm{m}$ to treat swine farm wastewater, the mean membrane flux was $159 \mathrm{~L} \cdot\left(\mathrm{m}^{2} \cdot \mathrm{h}\right)^{-1}$, the microfiltrate rejected $100 \%$ suspended solids and was fed to the RO system. Waeger et al. (2010) [32] pretreated the biogas digestate from a swine farm using ultrafiltration membrane with a pore size of $50 \mathrm{~nm}$, the membrane permeation flux decreased from 40 to $25 \mathrm{~L} \cdot\left(\mathrm{m}^{2} \cdot \mathrm{h}\right)^{-1}$, and a removal of $85 \%$ of the chemical oxygen demand (COD) was observed. Fugère et al. (2005) [33] used a hollow fiber ultrafiltration membrane with a pore size of $0.01 \mu \mathrm{m}$ to pretreat swine farm wastewater, the suspended solids was removed by $100 \%$ and the coliforms were removed at an efficiency effectiveness greater than 99\%. Zhan et al. (2018) [34] pretreated the biogas digestate from a swine farm with a hollow fiber ultrafiltration membrane with a pore size of 10 100 nm, the membrane flux was in the range of $9.0 \sim 16.7 \mathrm{~L} \cdot\left(\mathrm{m}^{2} \cdot \mathrm{h}\right)^{-1}$, over $95 \%$ of suspended solids was removed in the ultrafiltration permeate. These studies all showed that both CUFM and HFUFM could be applied as a pretreatment method for removing suspended solids.

However, there is no direct comparison between the effects of HFUFM and CUFM pretreatments on the performance of the NF or RO concentration process. Therefore, this study compared the hydraulic performance and nutrient concentration of an integrated process of NF + RO with HFUFM and CUFM pretreatments, using the biogas digestate from swine manure as the substrate. The objective was to provide scientific information for selecting membrane-based pretreatment methods for biogas digestate concentration in applications.

\section{Materials and Methods}

\subsection{Setup of Integrated Membrane Process}

A pilot-scale integrated membrane system consisting of hollow fiber ultrafiltration membrane (HFUFM) and ceramic membrane (CUFM) pretreatment followed by a combined nanofiltration (NF) and reverse osmosis $(\mathrm{RO})$ process $(\mathrm{NF}+\mathrm{RO})$ was built to concentrate biogas digestate (Figure 1). A tubular HFUFM module and a tubular CUFM module were used as separate pretreatments, the technical specifications of the two membrane modules were shown in Table 1. The two membrane modules chosen were the most commercially employed UF membrane modules. The membrane material and also the manufacturing method caused the difference in membrane pore size. The tubular NF and RO membrane were placed parallelly and horizontally, where a regular pump and a high-pressure pump were used to provide the pressure. The parts and materials for the membrane system including a paper filter, the CUFM module, the HFUFM module, and the NF and RO modules were supplied from the Hangzhou Rui Na Membrane Technology Co. Ltd. (Hangzhou, China). The technical specifications of NF and RO modules were shown in Table 1. 


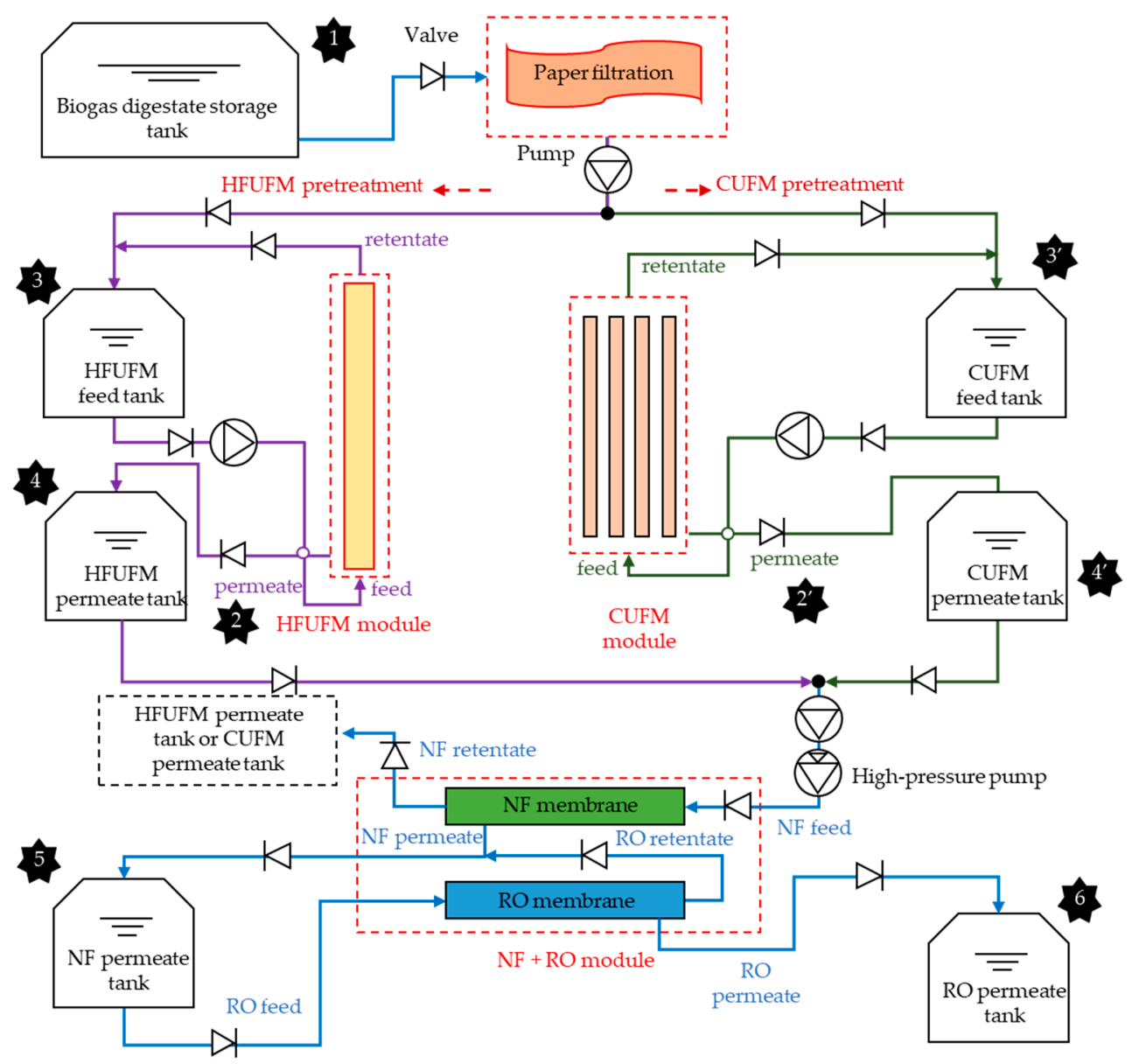

Figure 1. Schematic of the two combined processes under HFUFM and CUFM pretreatment. Sampling points 1 6: The original biogas digestate liquid (1), the HFUFM permeate (2), the CUFM permeate $\left(2^{\prime}\right)$, the HFUFM concentrate (3), the CUFM concentrate $\left(3^{\prime}\right)$, the NF concentrate (with HFUFM pretreatment (4), with CUFM pretreatment $\left(4^{\prime}\right)$ ), the RO concentrate (5), the RO permeate (6).

Table 1. Characteristics of ceramic membrane (CUFM), organic hollow fiber ultrafiltration membrane (HFUFM), nanofiltration (NF), and reverse osmosis (RO) membrane modules.

\begin{tabular}{ccccc}
\hline Parameter & $\begin{array}{c}\text { CUFM (Ceramic } \\
\text { Membrane) }\end{array}$ & $\begin{array}{c}\text { HFUFM (Hollow } \\
\text { Fiber Ultrafiltration } \\
\text { Membrane) }\end{array}$ & $\begin{array}{c}\text { NF (Nanofiltration } \\
\text { Membrane) }\end{array}$ & $\begin{array}{c}\text { RO (Reverse } \\
\text { Osmosis Membrane) }\end{array}$ \\
\hline Material & Ceramic CRM 301940 & $\begin{array}{c}\text { Polyvinylidene } \\
\text { fluoride (PVDF) }\end{array}$ & DOW NF 270-4040 & DOW BW 30-4040 \\
Filtration area $\left(\mathrm{m}^{2}\right)$ & 0.96 & 30 & 7.6 & 7.6 \\
Pore feature $(\mathrm{nm})$ & 200 & $10-100$ & $1-2$ & $<1$ \\
Filtration mechanism & Sieving & Sieving & Selective permeability & Selective permeability \\
Max. pressure $(\mathrm{bar})$ & 4 & 3 & 30 & 30 \\
Max. temperature $\left({ }^{\circ} \mathrm{C}\right)$ & 150 & 45 & 45 & 45 \\
pH range & $0-14$ & $2-10$ & $2-11$ & $2-11$ \\
\hline
\end{tabular}

\subsection{Experiment Design}

The biogas digestate was collected from a digestate storage pond in a large-scale swine farm in Hebei Province, China. The biogas digestate was randomly drawn into a $1 \mathrm{~m}^{3}$ water tank by a pump placed at the center of the pond, about $1 \mathrm{~m}$ below the surface. Four batches of biogas digestate $\left(1 \mathrm{~m}^{3}\right.$ each) were collected on four different days (shown in Table S1) at the same sampling location in December 2017. 
Four cross-repetition tests [10] were carried out for the treatment of the biogas digestate with a feed volume of $500 \mathrm{~L}$, using the combined concentrating process of NF $+\mathrm{RO}$ coupled with either the HFUFM pretreatment or the CUFM pretreatment, i.e., HFUFM + NF + RO and CUFM + NF + RO. The two integrated processes with four replicates ran in the following random sequence, i.e., the first process underwent experimental batches of $1,3,6$, and 8 , and the second process covered experimental batches of 2, 4, 5, and 7 (Table S1).

The working conditions of the HFUFM, CUFM, NF, and RO membrane modules were maintained following the manuals or the information from the existing research [23], the crossflow velocity is $0.12 \mathrm{~m} \cdot \mathrm{s}^{-1}$ for HFUFM and $3.5 \mathrm{~m} \cdot \mathrm{s}^{-1}$ for CUFM; the applied pressure is $0.6 \mathrm{bar}, 3 \mathrm{bar}, 6$ bar and $15 \mathrm{bar}$ for HFUFM, CUFM, NF, and RO modules, respectively; the volume concentration ratio (VCR, the ratio of the concentrate volume to the feed volume) of HFUFM and CUFM were both $1 / 6$ and that of NF and $\mathrm{RO}$ processes were both $1 / 5$. A short period of clean water washing, was performed to achieve a better recovery of initial permeate flux after each treatment of the batch of biogas slurry. The flux, the inlet and outlet pressures of the membrane modules, the water supply pressure, and the liquid temperature were measured at 5 min intervals. The flux was measured using a floating flow meter and the volume was measured using a tank level sensor. A pressure gauge and a temperature sensor were used to record the liquid pressure and temperature. All sensors were supplied by the Hangzhou Rui Na Membrane Technology Co. Ltd. (Hangzhou, China). Samples from the inlet liquid, the HFUFM permeate, the CUFM permeate, the HFUFM concentrate, the CUFM concentrate, the NF concentrate, and the $\mathrm{RO}$ permeate and concentrate were collected (Figure 1).

\subsection{Physico-Chemical Characterization of the Biogas Digestate from Swine Manure}

The physico-chemical characteristics of the biogas digestate from the swine manure and the analysis methods used were presented in Table 2. The physico-chemical parameters analyzed included $\mathrm{pH}$, turbidity, electrical conductivity (EC), total suspended solids (TSS), total solids (TS), volatile solids (VS), total phosphorus (TP), total nitrogen (TN), ammonia nitrogen $\left(\mathrm{NH}_{4}{ }^{+}-\mathrm{N}\right)$, chemical oxygen demand (COD), total organic carbon (TOC), metal ion (potassium, $\mathrm{K}^{+}$or total potassium (TK); calcium, $\mathrm{Ca}^{2+}$; sodium, $\mathrm{Na}^{+}$; magnesium, $\mathrm{Mg}^{2+}$ ), anion (chloride, $\mathrm{Cl}^{-}$; carbonate, $\mathrm{CO}_{3}{ }^{2-}$; bicarbonate, $\mathrm{HCO}_{3}{ }^{-}$), and antibiotics (Sulfadimethylpyrimidine, enrofloxacin, ciprofloxacin, oxytetracycline, doxycycline).

\subsection{Calculations and Statistical Analysis}

In the study, the data were compiled, calculated, analyzed, and plotted using Microsoft Excel 2016 (Microsoft, Redmond, WA, USA). Analysis of variance was conducted based on the independent sample $t$ test at a significance level of 0.05 , using the statistical package of IBM SPSS Statistics 20.0 (IBM, Armonk, NY, USA).

The removal rate, $\operatorname{Rr}(\%)$, denoted the percent reduction of the targeted substance in the permeate according to the following equation [35]:

$$
\operatorname{Rr}(\%)=\frac{C_{i}-C_{p}}{C_{i}} \times 100
$$

where $C_{i}$ was the concentration or content of the substance in the separated liquid and $C_{p}$ was the concentration or content of the substance in the permeate.

The nutrient concentration factor, $\mathrm{CF}$, was used to assess the concentration of the targeted substance in the concentrate according to the following equation [36]:

$$
\mathrm{CF}=\frac{C_{c}}{C_{i}}
$$

where $C_{c}$ was the concentration or content of the substance in the concentrate and $C_{i}$ was the concentration or content of the substance in the initial feed of biogas digestate. 
The volume concentration ratio (VCR) was defined as [8]:

$$
\mathrm{VCR}=\frac{V_{i}}{V_{i}-V_{p}}
$$

where $V_{i}$ was the volume of the initial feed of biogas digestate, $V_{i}$ and $V_{p}$ were the volumes of the influent and the permeate of the tested membrane process.

The membrane flux decline rate (FD, \%) was defined as [8]:

$$
\mathrm{FD}(\%)=\frac{J_{i}-J_{e}}{J_{i}}
$$

where $J_{i}$ was the initial membrane flux $\left(\mathrm{L} \cdot\left(\mathrm{m}^{2} \cdot \mathrm{h}\right)^{-1}\right)$ in a batch process, and $J_{e}$ was the membrane flux $\left(\mathrm{L} \cdot\left(\mathrm{m}^{2} \cdot \mathrm{h}\right)^{-1}\right)$ at the end of a batch process.

Table 2. The physico-chemical characteristics of swine manure digestate and the methods and equipment

\begin{tabular}{|c|c|c|}
\hline Parameters & Analytical Method & Biogas Digestate Content \\
\hline $\mathrm{pH}$ & $\mathrm{pH}$ glass electrode method & $7.60 \pm 0.04$ \\
\hline Electrical conductivity $(\mathrm{EC})\left(\mathrm{ms} \cdot \mathrm{cm}^{-1}\right)$ & Electrode method & $7.44 \pm 0.54$ \\
\hline Turbidity (NTU) & Infrared scattering & $318.8 \pm 56.1$ \\
\hline $\mathrm{NH}_{4}{ }^{+}-\mathrm{N}\left(\mathrm{mg} \cdot \mathrm{L}^{-1}\right)$ & Salicylic acid spectrophotometry & $745.8 \pm 12.3$ \\
\hline Total nitrogen $(\mathrm{TN})\left(\mathrm{mg} \cdot \mathrm{L}^{-1}\right)$ & Persulfate oxidation & $662.5 \pm 36.3$ \\
\hline Chemical oxygen demand (COD) $\left(\mathrm{mg} \cdot \mathrm{L}^{-1}\right)$ & $\begin{array}{l}\text { Potassium dichromate rapid digestion } \\
\text { spectrophotometry }\end{array}$ & $588.5 \pm 16.1$ \\
\hline Total phosphorus (TP) $\left(\mathrm{mg} \cdot \mathrm{L}^{-1}\right)$ & $\begin{array}{l}\text { Ammonium molybdenum } \\
\text { spectrophotometry }\end{array}$ & $48.04 \pm 3.77$ \\
\hline Total suspended solids (TSS) $\left(\mathrm{mg} \cdot \mathrm{L}^{-1}\right)$ & Filter paper drying weight method & $134.2 \pm 14.5$ \\
\hline Total solids $(\mathrm{TS})\left(\mathrm{mg} \cdot \mathrm{L}^{-1}\right)$ & Drying weight method & $2263 \pm 104$ \\
\hline Volatile solids (VS) $\left(\mathrm{mg} \cdot \mathrm{L}^{-1}\right)$ & Muffle furnace drying weight method & $750.7 \pm 112.7$ \\
\hline Total organic carbon $(\mathrm{TOC})\left(\mathrm{mg} \cdot \mathrm{L}^{-1}\right)$ & $\begin{array}{l}\text { Combustion oxidation-non-dispersive } \\
\text { infrared absorption method }\end{array}$ & $210.8 \pm 0.7$ \\
\hline Total potassium $(\mathrm{TK})\left(\mathrm{K}^{+}\right)\left(\mathrm{mg} \cdot \mathrm{L}^{-1}\right)$ & & 362 \\
\hline $\mathrm{Ca}^{2+}\left(\mathrm{mg} \cdot \mathrm{L}^{-1}\right)$ & Inductively coupled plasma optical & 32.6 \\
\hline $\mathrm{Na}^{+}\left(\mathrm{mg} \cdot \mathrm{L}^{-1}\right)$ & emission spectrometry & 290 \\
\hline $\mathrm{Mg}^{2+}\left(\mathrm{mg} \cdot \mathrm{L}^{-1}\right)$ & & 46.6 \\
\hline $\mathrm{Cl}^{-}\left(\mathrm{mg} \cdot \mathrm{L}^{-1}\right)$ & Ion chromatography & 304 \\
\hline $\mathrm{HCO}_{3}^{-}\left(\mathrm{mg} \cdot \mathrm{L}^{-1}\right)$ & Acid-base indicator titration, & 3880 \\
\hline $\mathrm{CO}_{3}^{2-}\left(\mathrm{mg} \cdot \mathrm{L}^{-1}\right)$ & potentiometric titration & 0 \\
\hline Sulfadimethylpyrimidine $\left(\mathrm{ng} \cdot \mathrm{mL}^{-1}\right)$ & & $405.8 \pm 15.5$ \\
\hline Enrofloxacin $\left(\mathrm{ng} \cdot \mathrm{mL}^{-1}\right)$ & & $2.03 \pm 0.03$ \\
\hline Ciprofloxacin $\left(\mathrm{ng} \cdot \mathrm{mL}^{-1}\right)$ & $\begin{array}{l}\text { Hign perrormance liquia } \\
\text { chromatography }\end{array}$ & $4.47 \pm 0.02$ \\
\hline Oxytetracycline $\left(\mathrm{ng} \cdot \mathrm{mL}^{-1}\right)$ & & $82.12 \pm 6.52$ \\
\hline Doxycycline $\left(\mathrm{ng} \cdot \mathrm{mL}^{-1}\right)$ & & $42.63 \pm 4.10$ \\
\hline
\end{tabular}
used for analysis.

\section{Results and Discussion}

\subsection{Influence of HFUFM and CUFM on the Flux Changes}

\subsubsection{Fluxes of HFUFM and CUFM Pretreatment}

The membrane fluxes of HFUFM and CUFM both showed a rapid decline with the running time (Figure 2a,b). The CUFM membrane permeation flux decreased from 180 to $100 \mathrm{~L} \cdot\left(\mathrm{m}^{2} \cdot \mathrm{h}\right)^{-1}$, and the HFUFM membrane permeation flux decreased from 35 to $17 \mathrm{~L} \cdot\left(\mathrm{m}^{2} \cdot \mathrm{h}\right)^{-1}$, with the former being about 5 times that of the latter, indicating that the membrane permeation property (membrane flux) of CUFM pretreatment was much higher. The average flux decline rate (FD, \%) for CUFM and HFUFM was $37.08 \% \pm 4.54 \%$ and $37.56 \% \pm 5.28 \%$, respectively, showing that there were no significant differences $(p>0.05)$, which indicated that the fouling characteristics of CUFM and HFUFM were similar in the batch process. The decline of the membrane flux was due to the forming of the cake 
layer on the membrane surface, which caused membrane fouling and resulted in a decrease of the membrane permeability [37]. The results were similar to the data from other studies presented in Table 3. The relatively high permeation property of the CUFM membrane was probably related to factors such as the pore size, membrane material, and applied pressures $[10,30,32,38]$.

The larger working pressure of CUFM ( 3 bar) than that of HFUFM ( 0.6 bar) was one of the factors that contributed to a higher permeation property (membrane flux) of CUFM. In addition, CUFM had a larger pore size $(200 \mathrm{~nm})$ than HFUFM $(10-100 \mathrm{~nm})$, they could be reasons for CUFM to achieve a higher permeation property. CUFM, which was made of inorganic ceramic, had a relatively higher crossflow velocity $\left(3.5 \mathrm{~m} \cdot \mathrm{s}^{-1}\right.$, provided by the manufacturer) than HFUFM $\left(0.12 \mathrm{~m} \cdot \mathrm{s}^{-1}\right.$, provided by the manufacturer), which was made of organic polymers. The higher crossflow velocity contributed to the higher membrane flux according to Salud, et al. (2019) [38].

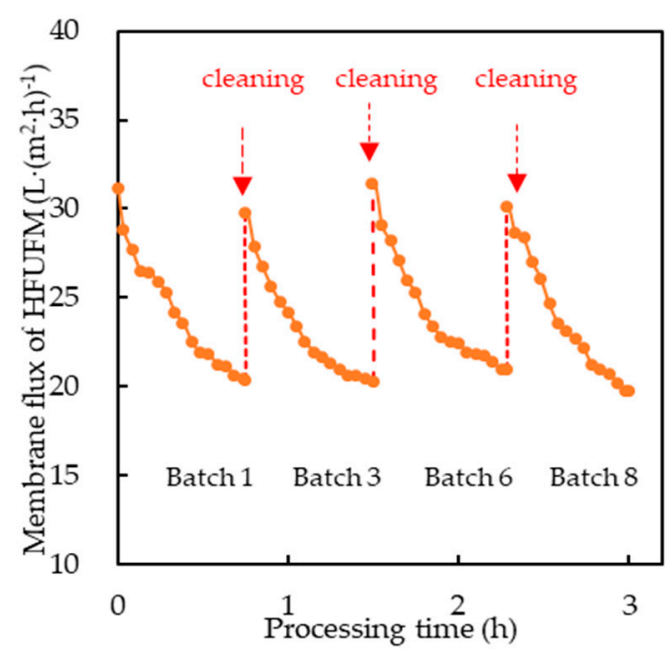

(a)

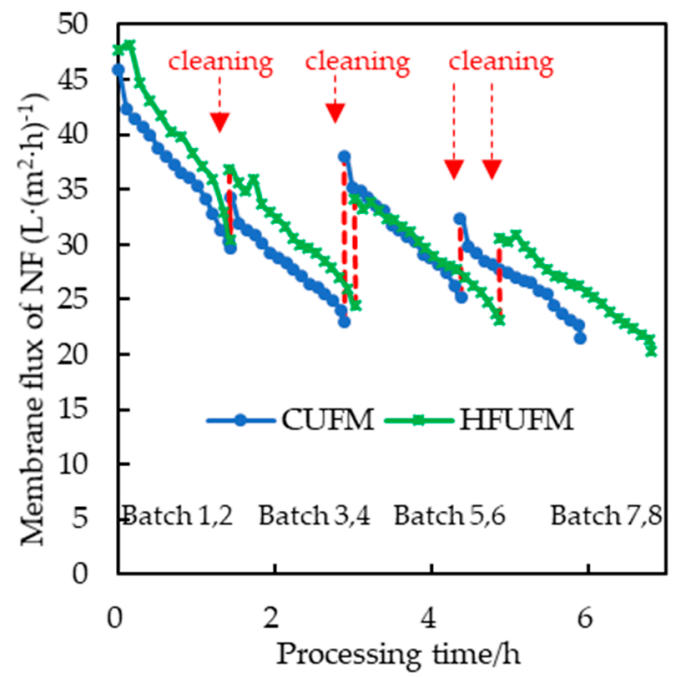

(c)

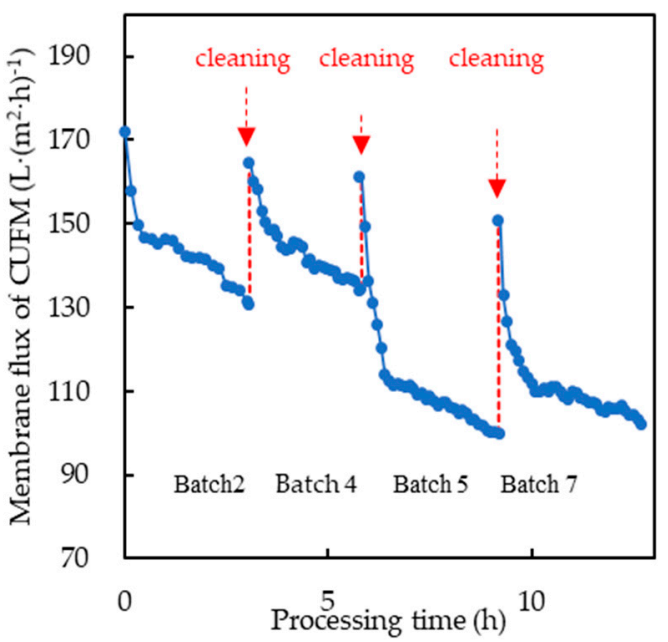

(b)

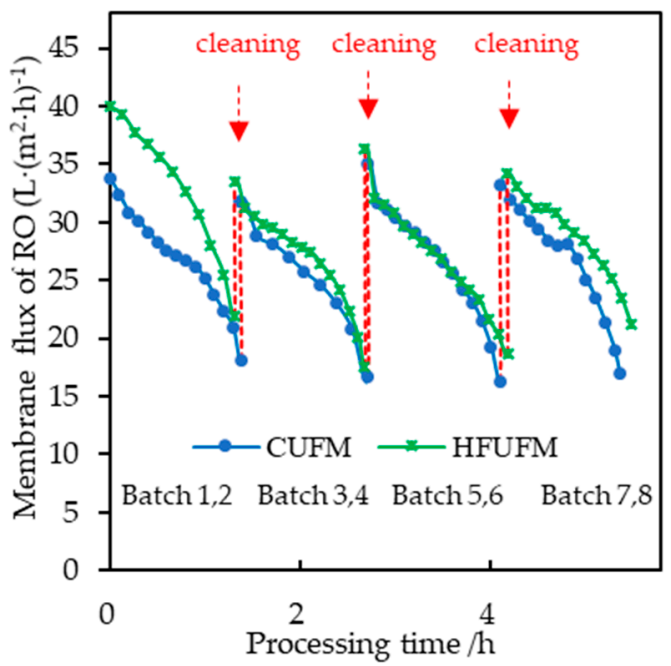

(d)

Figure 2. Membrane flux changes of (a)HFUFM pretreatment, (b) CUFM pretreatment, and (c) nanofiltration membrane (NF), (d) reverse osmosis (RO) process with HFUFM and CUFM pretreatment method.

\subsubsection{Fluxes of Combined NF+RO Process}

The variations of NF and RO membrane permeation fluxes with time for each experimental batch were shown in Figure 2c,d. The membrane permeation flux of NF varied from 20 to $48 \mathrm{~L} \cdot\left(\mathrm{m}^{2} \cdot \mathrm{h}\right)^{-1}$ with the HFUFM pretreatment, and from 22 to $46 \mathrm{~L} \cdot\left(\mathrm{m}^{2} \cdot \mathrm{h}\right)^{-1}$ with the CUFM pretreatment, respectively. 
The membrane flux of RO varied from 16 to $34 \mathrm{~L} \cdot\left(\mathrm{m}^{2} \cdot \mathrm{h}\right)^{-1}$ with the HFUFM pretreatment, and from 18 to $40 \mathrm{~L} \cdot\left(\mathrm{m}^{2} \cdot \mathrm{h}\right)^{-1}$ with the CUFM pretreatment, respectively. The slightly higher flux in NF and RO using HFUFM pretreatment than that using CUFM pretreatment was observed (Figure 2c,d). This little difference was probably due to the detected temperature difference of the inlet fluid from CUFM and HFUFM permeate. Studies [23,39] showed that a higher temperature of the inlet fluid of the NF and RO might cause the membrane flux to be higher. Therefore, compared to the CUFM, the higher temperature of HFUFM permeate might be the reason for a bit higher flux in NF and RO using HFUFM pretreatment. The average flux decline rate (FD, \%) for NF process with CUFM and HFUFM pretreatment was $33.83 \% \pm 1.55 \%$ and $33.9 \% \pm 1.01 \%$, respectively, and the average FD for RO process with CUFM and HFUFM pretreatment was $44.78 \% \pm 4.18 \%$ and $48.98 \% \pm 2.64 \%$, respectively. The results showed that there were no significant differences $(p>0.05)$ between the two pretreatments in both cases. On the whole, the different pretreatments showed no noticeable effect on the fluxes of both the NF and RO processes due possibly to the same operating regime and feed volume used for the NF $+\mathrm{RO}$ process.

Table 3. Studies applied HFUFM or CUFM process to pretreating the biogas digestate.

\begin{tabular}{|c|c|c|c|c|c|}
\hline $\begin{array}{l}\text { Applied } \\
\text { Process }\end{array}$ & $\begin{array}{l}\text { Pore Size } \\
\text { (nm) }\end{array}$ & $\begin{array}{c}\text { Working } \\
\text { Pressure (Bar) }\end{array}$ & $\begin{array}{c}\text { Membrane Flux } \\
\text { Range }\left(\mathrm{L} \cdot\left(\mathrm{m}^{2} \cdot \mathrm{h}\right)^{-1}\right)\end{array}$ & $\begin{array}{l}\text { Compared with } \\
\text { This Study }\end{array}$ & Studies \\
\hline \multirow{4}{*}{$\begin{array}{c}\text { HFUFM } \\
\text { pretreatment }\end{array}$} & 50 & 0.3 & $40.0 \sim 25.0$ & slightly larger & [32] \\
\hline & $10 \sim 100$ & 0.3 & 16.7 9.0 & slightly lower & [34] \\
\hline & 10 & 1 & $40.0 \sim 25.0$ & similar & [33] \\
\hline & $10 \sim 100$ & 0.6 & $35.0 \sim 17.0$ & & This study \\
\hline \multirow{4}{*}{$\begin{array}{c}\text { CUFM } \\
\text { pretreatment }\end{array}$} & 200 & 1 & $140.0 \sim 120.0$ & similar & [30] \\
\hline & 100 & 1.8 & reached 159.0 & similar & [31] \\
\hline & 200 & 3 & $80.0 \sim 120.0$ & similar & [23] \\
\hline & 200 & 3 & $180.0 \sim 100.0$ & & This study \\
\hline
\end{tabular}

As many kinds of molecules and ions were rejected and accumulated on the surface of NF and RO membrane, a blocking layer could be formed [28,40-42], which reduced the permeability of the membranes. In addition, the concentrations of molecules and ions also increased in the influent, which could further reduce the membrane permeability, resulting in the rapid decline of membrane fluxes of both NF and RO process (Figure 2c,d). However, after each cleaning, the permeability of the membranes was largely re-established because the molecules and ions accumulated on the membrane surface were removed [20], which rejuvenated the membrane permeability, leading to the recovery of the membrane permeation fluxes.

\subsection{Characteristics of CUFM Permeate and HFUFM Permeate}

The physico-chemical properties of CUFM permeate and HFUFM permeate were shown in Table 4. Comparing with the biogas digestate, both CUFM permeate and HFUFM permeate showed an effective effect in removing turbidity and total suspended solids (TSS), with a removal rate (Rr) for turbidity of $95.50 \% \pm 0.87 \%$ and $90.20 \% \pm 1.04 \%$, and a removal rate for TSS of $92.60 \% \pm 1.67 \%, 89.36 \% \pm 2.23 \%$, respectively. The Rr of both turbidity and TSS in CUFM permeate was a little higher than that in HFUFM permeate, this might be due to the smaller membrane filtration area of CUFM (Table 1, $0.96 \mathrm{~m}^{2}$ ) than that of HFUFM $\left(30 \mathrm{~m}^{2}\right)$, which made the suspended solids have less chance to pass through and resulted in a relatively lower $\mathrm{Rr}$. On the other hand, the $\mathrm{Rr}$ for COD was $29.13 \% \pm 1.87 \%$ and $28.76 \%$ $\pm 1.10 \%$, the $\operatorname{Rr}$ for TS was $50.00 \% \pm 1.40 \%$ and $46.61 \% \pm 3.04 \%$, the $\operatorname{Rr}$ for TP was $60.65 \% \pm 0.76 \%$ and $65.73 \% \pm 0.93 \%$, in CUFM and HFUFM permeate, respectively. The relatively high Rr for TP in both permeates might be related to the phosphorus solidification. Masse, et al. (2005) [24] reported that phosphorus was predominantly linked to particles between 0.45 and $10 \mathrm{~mm}$. The Rr for EC, VS, $\mathrm{TN}, \mathrm{NH}_{4}{ }^{+}-\mathrm{N}$ and antibiotics was below $20 \%$ both in CUFM permeate and HFUFM permeate, and the content of $\mathrm{K}^{+}, \mathrm{Ca}^{2+}, \mathrm{Na}^{+}, \mathrm{Mg}^{2+}, \mathrm{Cl}^{-}$, and $\mathrm{HCO}_{3}{ }^{-}$didn't decrease much compared with the content 
in the biogas digestate. These results were similar to other studies mentioned in the introduction part, which showed that UF pretreatment only had a significant effect on removing suspended solids, which would not only reduce membrane fouling of the NF and RO process, but also retain nutrients for NF and RO concentration.

Table 4. The physico-chemical characteristics of the biogas digestate and the CUFM permeate and HFUFM permeate (mean $\pm \mathrm{SD}$ ).

\begin{tabular}{|c|c|c|c|}
\hline Parameters & Biogas Digestate & CUFM Permeate & HFUFM Permeate \\
\hline $\mathrm{pH}$ & $7.60 \pm 0.04$ & $7.96 \pm 0.02$ & $7.90 \pm 0.09$ \\
\hline $\mathrm{EC}\left(\mathrm{ms} \cdot \mathrm{cm}^{-1}\right)$ & $7.44 \pm 0.54$ & $6.61 \pm 0.34$ & $6.50 \pm 0.63$ \\
\hline Turbidity (NTU) & $318.8 \pm 56.1$ & $15.90 \pm 0.28$ & $31.25 \pm 0.38$ \\
\hline $\mathrm{NH}_{4}{ }^{+}-\mathrm{N}\left(\mathrm{mg} \cdot \mathrm{L}^{-1}\right)$ & $745.8 \pm 12.3$ & $528.50 \pm 22.96$ & $531.25 \pm 27.27$ \\
\hline $\mathrm{TN}\left(\mathrm{mg} \cdot \mathrm{L}^{-1}\right)$ & $662.5 \pm 36.3$ & $562.50 \pm 96.01$ & $535 \pm 78.26$ \\
\hline $\operatorname{COD}\left(\mathrm{mg} \cdot \mathrm{L}^{-1}\right)$ & $588.5 \pm 16.1$ & $546.00 \pm 53.39$ & $527 \pm 48.42$ \\
\hline $\mathrm{TP}\left(\mathrm{mg} \cdot \mathrm{L}^{-1}\right)$ & $48.04 \pm 3.77$ & $18.90 \pm 2.88$ & $16.46 \pm 2.92$ \\
\hline TSS $\left(\mathrm{mg} \cdot \mathrm{L}^{-1}\right)$ & $134.2 \pm 14.5$ & $10.67 \pm 3.77$ & $13.67 \pm 5.73$ \\
\hline $\mathrm{TS}\left(\mathrm{mg} \cdot \mathrm{L}^{-1}\right)$ & $2263 \pm 104$ & $1131.33 \pm 145.72$ & $1208.00 \pm 73.97$ \\
\hline $\mathrm{VS}\left(\mathrm{mg} \cdot \mathrm{L}^{-1}\right)$ & $750.7 \pm 112.7$ & $533.33 \pm 54.09$ & $598.67 \pm 44.58$ \\
\hline $\mathrm{TOC}\left(\mathrm{mg} \cdot \mathrm{L}^{-1}\right)$ & $210.8 \pm 0.7$ & $172.63 \pm 0.97$ & $145.973 \pm 1.64$ \\
\hline $\mathrm{TK}\left(\mathrm{K}^{+}\right)\left(\mathrm{mg} \cdot \mathrm{L}^{-1}\right)$ & 362 & 404 & 314 \\
\hline $\mathrm{Ca}^{2+}\left(\mathrm{mg} \cdot \mathrm{L}^{-1}\right)$ & 32.6 & 48.9 & 46.4 \\
\hline $\mathrm{Na}^{+}\left(\mathrm{mg} \cdot \mathrm{L}^{-1}\right)$ & 290 & 283 & 236 \\
\hline $\mathrm{Mg}^{2+}\left(\mathrm{mg} \cdot \mathrm{L}^{-1}\right)$ & 46.6 & 47.4 & 46.3 \\
\hline $\mathrm{Cl}^{-}\left(\mathrm{mg} \cdot \mathrm{L}^{-1}\right)$ & 304 & 281 & 275 \\
\hline $\mathrm{HCO}_{3}{ }^{-}\left(\mathrm{mg} \cdot \mathrm{L}^{-1}\right)$ & 3880 & 3650 & 3420 \\
\hline $\mathrm{CO}_{3}^{2-}\left(\mathrm{mg} \cdot \mathrm{L}^{-1}\right)$ & 0 & 0 & 0 \\
\hline Sulfadimethylpyrimidine $\left(\mathrm{ng} \cdot \mathrm{mL}^{-1}\right)$ & $405.8 \pm 15.5$ & $282.14 \pm 46.9$ & $399.90 \pm 7.87$ \\
\hline Enrofloxacin $\left(\mathrm{ng} \cdot \mathrm{mL}^{-1}\right)$ & $2.03 \pm 0.03$ & $1.94 \pm 0.04$ & $1.98 \pm 0.06$ \\
\hline Ciprofloxacin $\left(\mathrm{ng} \cdot \mathrm{mL}^{-1}\right)$ & $4.47 \pm 0.02$ & $4.40 \pm 0.11$ & $4.44 \pm 0.01$ \\
\hline Oxytetracycline $\left(\mathrm{ng} \cdot \mathrm{mL}^{-1}\right)$ & $82.12 \pm 6.52$ & $55.71 \pm 8.65$ & $83.36 \pm 6.54$ \\
\hline Doxycycline $\left(\mathrm{ng} \cdot \mathrm{mL}^{-1}\right)$ & $42.63 \pm 4.10$ & $26.09 \pm 1.11$ & $35.23 \pm 1.74$ \\
\hline
\end{tabular}

\subsection{Characteristics of RO Permeates of the Integrated Process}

The average volume permeation ratio of the RO process in the four batch tests with HFUFM and CUFM pretreatments showed no significant difference $(52.68 \% \pm 0.99 \%, 51.79 \% \pm 1.03 \%$, respectively). The physico-chemical properties of the RO permeate were shown in Table 5, and the associated Rrs were included in Figure S1. There were no significant differences $(p>0.05)$ in the RO permeate between HFUFM and CUFM pretreatments according to the Rrs of turbidity, TSS, TS, VS, COD, TOC, EC, TN, $\mathrm{NH}_{4}{ }^{+}-\mathrm{N}, \mathrm{K}^{+}, \mathrm{Ca}^{2+}, \mathrm{Na}^{+}, \mathrm{Mg}^{2+}, \mathrm{TP}$, and $\mathrm{Cl}^{-}$.

In general, as shown in Figure S1a, the Rrs were above 97\% for turbidity, TSS, TS, and VS; above 91\% for $\mathrm{EC}, \mathrm{TN}$, and $\mathrm{NH}_{4}{ }^{+}-\mathrm{N}$; above $98 \%$ for COD and TOC; above $91 \%$ for $\mathrm{EC}, \mathrm{TN}$, and $\mathrm{NH}_{4}{ }^{+}-\mathrm{N}$; above $98 \%$ for $\mathrm{TP}$; above $95 \%$ for $\mathrm{K}^{+}, \mathrm{Ca}^{2+}, \mathrm{Na}^{+}$, and $\mathrm{Mg}^{2+}$; and above $95 \%$ for $\mathrm{Cl}^{-}$. The contents of COD, TSS, $\mathrm{NH}_{4}{ }^{+}-\mathrm{N}$, and TP were lower than the allowable values in the National Discharge Standard of Pollutants for Livestock and Poultry Breeding (GB 18596-2001) [43]. The contents of COD, TSS, and $\mathrm{Cl}^{-}$were lower than the allowable values in the National Standards for Irrigation Water Quality (GB 5084-2005) [44].

In early studies, Caide (2018) [23] used a CUFM membrane as pretreatment of swine farm biogas digestate and a tubular NF and RO membrane for further treatment. In the final RO permeate, COD and $\mathrm{NH}_{4}{ }^{+}-\mathrm{N}$ were removed by $97.60 \%$ and $88.50 \%$, respectively. Ruan et al. (2015) [20] used a HFUFM membrane to pretreat the swine farm biogas digestate, and a polyamide $\mathrm{RO}$ membrane for further treatment. In the RO permeate, the contents of COD and $\mathrm{NH}_{4}{ }^{+}-\mathrm{N}$ were both lower than $50 \mathrm{mg} \cdot \mathrm{L}^{-1}$, and the Rrs were higher than $90 \%$. Similar results were observed in this study. The solid, organic matter, and ions in the RO permeate could be almost completely removed using either the HFUFM 
or CUFM pretreatment. The RO permeates produced could be reused for house backwashing, boiler cooling, etc.

For antibiotics of sulfadimethylpyrimidine, enrofloxacin, ciprofloxacin, and doxycycline in the RO permeate, they were completely removed with removal rate of $100 \%$, as shown in Figure S1b. However, in the RO permeates with CUFM and HFUFM pretreatment, the Rrs of oxytetracycline were $76.8 \% \pm 16.9 \%$ and $59.7 \% \pm 9.3 \%$ with $19.0 \pm 13.5 \mathrm{ng} \cdot \mathrm{mL}^{-1}$ and $33.1 \pm 7.4 \mathrm{ng} \cdot \mathrm{mL}^{-1}$ left, respectively. In the RO permeate, the remaining oxytetracycline could still pose a threat to the environment $[45,46]$. Further treatment is needed before disposal.

Table 5. The physicochemical properties of the $\mathrm{RO}$ permeate from the biogas digestate treated using the NF + RO processes with HFUFM and CUFM (mean \pm SD).

\begin{tabular}{|c|c|c|c|c|}
\hline Parameters & $\begin{array}{c}\text { RO Permeate with } \\
\text { HFUFM } \\
\text { Pretreatment Method }\end{array}$ & $\begin{array}{l}\text { RO Permeate with } \\
\text { CUFM } \\
\text { Pretreatment Method }\end{array}$ & $\begin{array}{l}\text { Discharge Standard of } \\
\text { Pollutants for Livestock } \\
\text { and Poultry Breeding } \\
\text { (GB 18596-2001) [43] }\end{array}$ & $\begin{array}{c}\text { Standards for Irrigation } \\
\text { Water Quality } \\
\text { (GB 5084-2005) [44] }\end{array}$ \\
\hline $\mathrm{pH}$ & $8.76 \pm 0.40$ & $9.06 \pm 0.03$ & - & $5.5 \sim 8.5$ \\
\hline $\mathrm{EC}\left(\mathrm{ms} \cdot \mathrm{cm}^{-1}\right)$ & $0.39 \pm 0.08$ & $0.40 \pm 0.06$ & - & - \\
\hline Turbidity (NTU) & $0.40 \pm 0.20$ & $0.22 \pm 0.02$ & - & - \\
\hline $\mathrm{COD}\left(\mathrm{mg} \cdot \mathrm{L}^{-1}\right)$ & $3.0 \pm 2.1$ & $8.0 \pm 1.2$ & 400 & 150 \\
\hline $\mathrm{TN}\left(\mathrm{mg} \cdot \mathrm{L}^{-1}\right)$ & $45.8 \pm 8.0$ & $49.0 \pm 12.8$ & - & - \\
\hline $\mathrm{NH}_{4}{ }^{+}-\mathrm{N}\left(\mathrm{mg} \cdot \mathrm{L}^{-1}\right)$ & $45.8 \pm 6.8$ & $47.6 \pm 7.9$ & 80 & - \\
\hline $\mathrm{TP}\left(\mathrm{mg} \cdot \mathrm{L}^{-1}\right)$ & $0.20 \pm 0.17$ & $0.68 \pm 0.10$ & 8.0 & - \\
\hline $\mathrm{TSS}\left(\mathrm{mg} \cdot \mathrm{L}^{-1}\right)$ & $0.0 \pm 1.6$ & $0.0 \pm 1.6$ & 200 & 80 \\
\hline $\mathrm{TS}\left(\mathrm{mg} \cdot \mathrm{L}^{-1}\right)$ & $62.7 \pm 15.4$ & $65.3 \pm 4.1$ & - & - \\
\hline $\mathrm{VS}\left(\mathrm{mg} \cdot \mathrm{L}^{-1}\right)$ & $10.0 \pm 4.3$ & $12.0 \pm 3.3$ & - & - \\
\hline $\mathrm{TOC}\left(\mathrm{mg} \cdot \mathrm{L}^{-1}\right)$ & $1.3 \pm 0.1$ & $1.5 \pm 0.2$ & - & - \\
\hline $\mathrm{HCO}_{3}^{-}\left(\mathrm{mg} \cdot \mathrm{L}^{-1}\right)$ & 70.9 & $67.8 \pm 3.4$ & - & - \\
\hline $\mathrm{CO}_{3}^{2-}\left(\mathrm{mg} \cdot \mathrm{L}^{-1}\right)$ & $72.7 \pm 3.7$ & $93.9 \pm 4.7$ & - & - \\
\hline $\mathrm{K}^{+}\left(\mathrm{mg} \cdot \mathrm{L}^{-1}\right)$ & $13.6 \pm 0.7$ & $14.9 \pm 0.8$ & - & - \\
\hline $\mathrm{Ca}^{2+}\left(\mathrm{mg} \cdot \mathrm{L}^{-1}\right)$ & $1.08 \pm 0.06$ & $1.58 \pm 0.08$ & - & - \\
\hline $\mathrm{Na}^{+}\left(\mathrm{mg} \cdot \mathrm{L}^{-1}\right)$ & $10.8 \pm 0.5$ & $11.6 \pm 0.2$ & - & - \\
\hline $\mathrm{Mg}^{2+}\left(\mathrm{mg} \cdot \mathrm{L}^{-1}\right)$ & $0.65 \pm 0.04$ & $0.77 \pm 0.39$ & - & - \\
\hline $\mathrm{Cl}^{-}\left(\mathrm{mg} \cdot \mathrm{L}^{-1}\right)$ & $14.6 \pm 0.7$ & $16.3 \pm 0.9$ & - & 350 \\
\hline $\begin{array}{c}\text { Sulfadimethylpyrimidine } \\
\left(\mathrm{ng} \cdot \mathrm{mL}^{-1}\right)\end{array}$ & $2.1 \pm 0.4$ & $1.9 \pm 0.5$ & - & - \\
\hline Enrofloxacin $\left(\mathrm{ng} \cdot \mathrm{mL}^{-1}\right)$ & 0 & 0 & - & - \\
\hline Ciprofloxacin $\left(\mathrm{ng} \cdot \mathrm{mL}^{-1}\right)$ & 0 & 0 & - & - \\
\hline Oxytetracycline $\left(\mathrm{ng} \cdot \mathrm{mL}^{-1}\right)$ & $33.1 \pm 7.4$ & $19.0 \pm 13.5$ & - & - \\
\hline Doxycycline $\left(\mathrm{ng} \cdot \mathrm{mL}^{-1}\right)$ & 0 & 0 & - & - \\
\hline
\end{tabular}

\subsection{Characteristics of the Concentrates of the Integrated Process}

The volume concentration ratio (VCR) of HFUFM and CUFM pretreatments were both 6 and the VCR of NF and RO processes were both 5 . The contents of TN, $\mathrm{NH}_{4}{ }^{+}-\mathrm{N}, \mathrm{TK}, \mathrm{TP}, \mathrm{COD}$, and TOC in different concentrates with HFUFM and CUFM pretreatments were shown in Figure S2. The nutrient concentration factors (CFs) were summarized as shown in Figure 3.

The contents of $\mathrm{TN}, \mathrm{NH}_{4}{ }^{+}-\mathrm{N}, \mathrm{TK}$, and TP in the concentrates showed no significant difference between the HFUFM and CUFM pretreatments (Figure S2a-c), except that the TK content in the NF concentrate with the CUFM pretreatment was slightly higher than that with the HFUFM pretreatment (Figure S2d). The average CFs of TN and TK in the HFUFM and CUFM concentrates were close to 1, showing no concentration effect. But in the NF concentrates, the average CFs of TN, TK increased to 1.62 and 1.94 by HFUFM pretreatment, and 1.60 and 2.14 by CUFM pretreatment. In the RO concentrates, they increased to 2.12 and 2.33 by HFUFM pretreatment and 2.19 and 2.33 by CUFM pretreatment. The CFs of TP were close to or lower than 1 in the concentrates, indicating that there was no concentration effect for TP. This might be due to phosphorus solidification in the slurry [22].

In the HFUFM and CUFM concentrates, the CFs of COD were 1.03 and 1.88, respectively, and those for TOC were 0.91 and 1.95 , respectively. The contents of COD and TOC in the CUFM concentrates were significantly higher than those in the HFUFM concentrates $(p<0.01)$, but they were not significantly different $(p>0.05)$ between the NF and RO concentrates (Figure S2e,f). COD and TOC were concentrated in the NF concentrates with HFUFM or CUFM pretreatment, the CFs were $2.40,2.55$ or $2.40,2.60$, respectively. But they were not concentrated in the RO concentrates. The CFs 
were blow 1, which indicated that COD and TOC were only rejected by the NF process. The contents of COD in the RO permeates with HFUFM and CUFM pretreatments were $380.00 \pm 16.79 \mathrm{mg} \cdot \mathrm{L}^{-1}$ and $402.00 \pm 27.83 \mathrm{mg} \cdot \mathrm{L}^{-1}$, which was close to the values in the discharge standard, GB 18596-2001 $\left(400 \mathrm{mg} \cdot \mathrm{L}^{-1}\right)$.

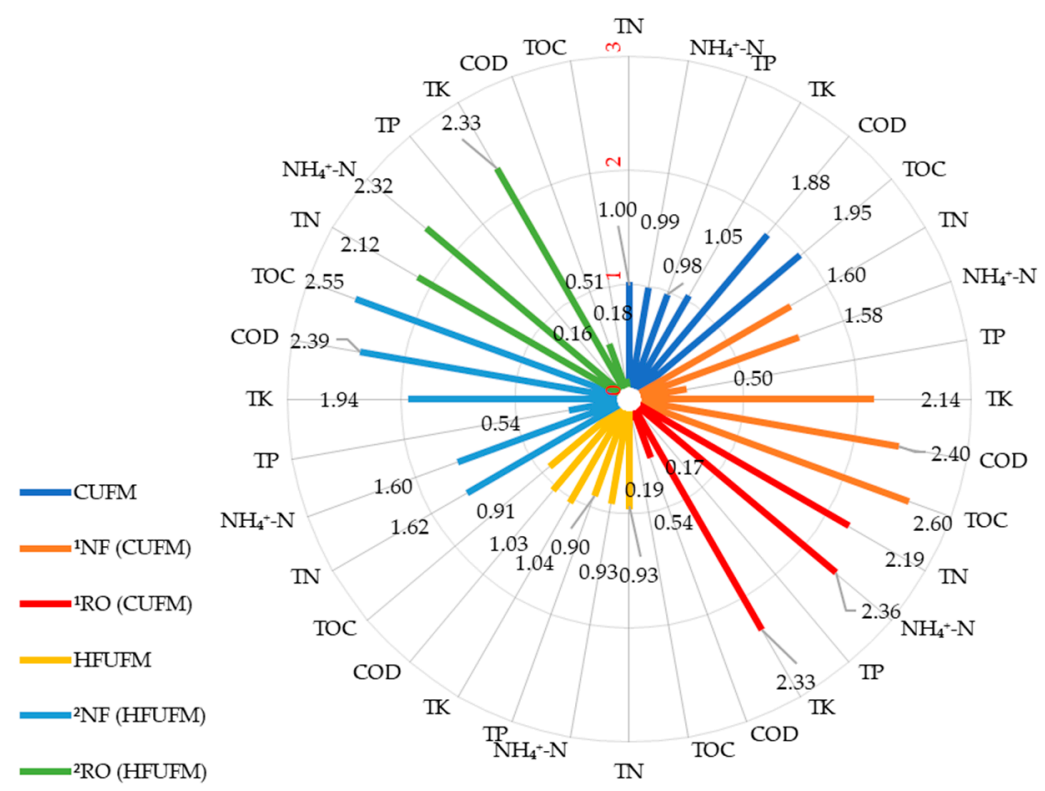

Figure 3. The average concentration factors of $\mathrm{TN}, \mathrm{NH}_{4}{ }^{+}-\mathrm{N}, \mathrm{TP}, \mathrm{TK}, \mathrm{COD}$, and TOC in the concentrates of the integrated process with HFUFM and CUFM pretreatments. Note: ${ }^{1} \mathrm{NF}$ (CUFM), ${ }^{1} \mathrm{RO}(\mathrm{CUFM})$, and ${ }^{2} \mathrm{NF}$ (HFUFM), ${ }^{2} \mathrm{RO}$ (HFUFM) means NF concentrate, RO concentrate with CUFM pretreatment, and NF concentrate, $\mathrm{RO}$ concentrate with HFUFM pretreatment, respectively.

The HFUFM and CUFM concentrates could be returned to the digestion process or the biogas digestate storage pond. The NF and RO concentrates both contained concentrated $\mathrm{TN}, \mathrm{NH}_{4}{ }^{+}-\mathrm{N}_{\text {, }}$ and TK, which was also reported in other studies [8,20,47]. Since N, P, K, and organic matter are the main plant nutrients [7,47], the concentrates produced can thus be used as a valuable organic fertilizer for crop growth. Moreover, the RO concentrates contained a higher concentration of $\mathrm{N}$ and $\mathrm{K}$ but a lower content of COD and TOC than the NF concentrates.

On the other hand, the NF and RO concentrates also contained antibiotics of sulfamethazine, enrofloxacin, ciprofloxacin, oxytetracycline, and doxycycline as shown in Figure S3. Thus, further attention should be paid to the antibiotics risks in the NF and RO concentrates before they could be utilized as an organic fertilizer for plants. In addition, the antibiotics content in the RO concentrates were significantly lower than that in the NF concentrates, indicating that the integrated $\mathrm{NF}+\mathrm{RO}$ process could be a solution to reduce the risk of antibiotics in the RO concentrate.

\section{Conclusions}

HFUFM and CUFM pretreatments were applied for NF + RO process of treating biogas digestate (500 L), CUFM showed a higher membrane flux than that of HFUFM $\left(100 \sim 180 \mathrm{~L} \cdot\left(\mathrm{m}^{2} \cdot \mathrm{h}\right)^{-1} \mathrm{vs}\right.$. 17 35 L $\left.\cdot\left(\mathrm{m}^{2} \cdot \mathrm{h}\right)^{-1}\right)$. NF + RO process performance with HFUFM and CUFM showed little difference. The flux of NF and RO decreased $\left(20 \sim 48 \mathrm{~L} \cdot\left(\mathrm{m}^{2} \cdot \mathrm{h}\right)^{-1}\right.$ and $\left.16 \sim 40 \mathrm{~L} \cdot\left(\mathrm{m}^{2} \cdot \mathrm{h}\right)^{-1}\right)$. In the RO permeates, TS, $\mathrm{COD}, \mathrm{TP}, \mathrm{Cl}^{-}, \mathrm{EC}$, and $\mathrm{TN}$ were removed by above $91 \%$ and sulfadimethylpyrimidine, enrofloxacin, ciprofloxacin, and doxycycline were removed by $100 \%$. In the concentrates (VCR = 5), TN and TK were concentrated about 1.60, 2.00 folds in NF stage, and about 2.10, 2.30 folds in RO stage. Further treatment for the antibiotics risks in the concentrates should be considered before they are utilized as plant fertilizers. Based on the results of effects on the membrane flux and the product quality, CUFM is 
suggested a better choice than HFUFM as the pretreatment of NF and RO in batch process. However, further studies should be conducted to investigate the fouling stability of the integrated membrane process in long run tests.

Supplementary Materials: The following are available online at http://www.mdpi.com/2077-0375/10/10/249/s1, Table S1: The different batches of the biogas digestate from swine manure, Figure S1: The Rrs (\%) of (a) physical and chemical parameters and (b) antibiotics content in RO permeates with HFUFM and CUFM pretreatment method. Figure S2: The content of (a) TN, (b) $\mathrm{NH}_{4}{ }^{+}-\mathrm{N}$, (c) TP, (d) TK, (e) COD, (f) TOC in the concentrates of the integrated process with HFUFM and CUFM pretreatments. Figure S3: The content of (a) sulfadimethylpyrimidine, (b) enrofloxacin and ciprofloxacin, (c) oxytetracycline, (d) doxycycline in the concentrates of the integrated process with HFUFM and CUFM pretreatment.

Author Contributions: Y.Z.: Experiments, data analysis, and Writing-Original draft preparation. F.Y.: Methodology, assisting in data analysis and reviewing. C.Y.: Conceptualization, experiment assistance. J.Z.: Writing-Reviewing and Editing. Z.Z., M.Z.: experiment assistance. H.D.: conceiving this study, coordination and reviewing the manuscript. All authors have read and agreed to the published version of the manuscript.

Funding: This research was funded by the China Agriculture Research System (CARS-35-10B), and the Central Public-Interest Scientific Institution Basal Research Fund (NO. BSRF201912).

Acknowledgments: Authors want to thank all our colleagues for their constructive suggestions and support during this study.

Conflicts of Interest: The authors declare no conflict of interest. The funders had no role in the design of the study; in the collection, analyses, or interpretation of data; in the writing of the manuscript, or in the decision to publish the results.

\section{References}

1. Hu, Y.; Cheng, H.; Tao, S. Environmental and human health challenges of industrial livestock and poultry farming in China and their mitigation. Environ. Int. 2017, 107, 111-130. [CrossRef] [PubMed]

2. Świątczak, P.; Cydzik-Kwiatkowska, A.; Zielińska, M. Treatment of the liquid phase of digestate from a biogas plant for water reuse. Bioresour. Technol. 2019, 276, 226-235. [CrossRef] [PubMed]

3. Nagarajan, D.; Kusmayadi, A.; Yen, H.W.; Dong, C.D.; Lee, D.J.; Chang, J.S. Current advances in biological swine wastewater treatment using microalgae-based processes. Bioresour. Technol. 2019, 289, 121718. [CrossRef] [PubMed]

4. Nkoa, R. Agricultural benefits and environmental risks of soil fertilization with anaerobic digestates: A review. Agron. Sustain. Dev. 2014, 34, 473-492. [CrossRef]

5. Cheng, D.L.; Ngo, H.H.; Guo, W.S.; Chang, S.W.; Nguyen, D.D.; Kumar, S.M. Microalgae biomass from swine wastewater and its conversion to bioenergy. Bioresour. Technol. 2019, 275, 109-122. [CrossRef]

6. Mortola, N.; Romaniuk, R.; Cosentino, V.; Eiza, M.; Carfagno, P.; Rizzo, P.; Bres, P.; Riera, N.; Roba, M.; Butti, M.; et al. Potential Use of a Poultry Manure Digestate as a Biofertiliser: Evaluation of Soil Properties and Lactuca sativa Growth. Pedosphere 2019, 29, 60-69. [CrossRef]

7. Sigurnjak, I.; Vaneeckhaute, C.; Michels, E.; Ryckaert, B.; Ghekiere, G.; Tack, F.M.G.; Meers, E. Fertilizer performance of liquid fraction of digestate as synthetic nitrogen substitute in silage maize cultivation for three consecutive years. Sci. Total Environ. 2017, 599, 1885-1894. [CrossRef]

8. Zhou, Z.; Chen, L.; Wu, Q.; Zheng, T.; Yuan, H.; Peng, N.; He, M. The valorization of biogas slurry with a pilot dual stage reverse osmosis membrane process. Chem. Eng. Res. Des. 2019, 142, 133-142. [CrossRef]

9. Xia, Q.C.; Liu, M.L.; Cao, X.L.; Wang, Y.; Xing, W.; Sun, S.P. Structure design and applications of dual-layer polymeric membranes. J. Membr. Sci. 2018, 562, 85-111. [CrossRef]

10. Sandoval, A.D.O.; Brião, V.B.; Fernandes, V.M.C.; Hemkemeier, A.; Friedrich, M.T. Stormwater management by microfiltration and ultrafiltration treatment. J. Water Process. Eng. 2019, 30, 100453. [CrossRef]

11. Andrade, L.H.; Mendes, F.D.D.S.; Cerqueira, N.; Espindola, J.C.; Amaral, M.C.S. Fouling evaluation in a MBR for dairy effluent treatment. Desalin. Water Treat. 2016, 57, 11919-11930. [CrossRef]

12. Ağtaş, M.; Yılmaz, Ö.; Dilaver, M.; Alp, K.; Koyuncu, İ. Hot water recovery and reuse in textile sector with pilot scale ceramic ultrafiltration/nanofiltration membrane system. J. Clean. Prod. 2020, 256, 120359. [CrossRef]

13. Castro-Munoz, R. The Role of New Inorganic Materials in Composite Membranes for Water Disinfection. Membranes 2020, 10, 101. [CrossRef] [PubMed] 
14. Konieczny, K.; Kwiecińska, A.; Gworek, B. The recovery of water from slurry produced in high density livestock farming with the use of membrane processes. Sep. Purif. Technol. 2011, 80, 490-498. [CrossRef]

15. Makara, A.; Kowalski, Z. Pig manure treatment and purification by filtration. J. Environ. Manag. 2015, 161, 317-324. [CrossRef]

16. Masse, L.; Massé, D.I.; Pellerin, Y. The use of membranes for the treatment of manure: A critical literature review. Biosyst. Eng. 2007, 98,371-380. [CrossRef]

17. Gienau, T.; Ehrmanntraut, A.; Kraume, M.; Rosenberger, S. Influence of Ozone Treatment on Ultrafiltration Performance and Nutrient Flow in a Membrane Based Nutrient Recovery Process from Anaerobic Digestate. Membranes 2020, 10, 64. [CrossRef]

18. Zacharof, M.-P.; Mandale, S.J.; Williams, P.M.; Lovitt, R.W. Nanofiltration of treated digested agricultural wastewater for recovery of carboxylic acids. J. Clean. Prod. 2016, 112, 4749-4761. [CrossRef]

19. Garcia-Ivars, J.; Martella, L.; Massella, M.; Carbonell-Alcaina, C.; Alcaina-Miranda, M.I.; Iborra-Clar, M.I. Nanofiltration as tertiary treatment method for removing trace pharmaceutically active compounds in wastewater from wastewater treatment plants. Water Res. 2017, 125, 360-373. [CrossRef]

20. Ruan, H.; Yang, Z.; Lin, J.; Shen, J.; Ji, J.; Gao, C.; Van der Bruggen, B. Biogas slurry concentration hybrid membrane process: Pilot-testing and RO membrane cleaning. Desalination 2015, 368, 171-180. [CrossRef]

21. Longlong, D.; Zhiye, Z.; Meng, W.; Bangxi, Z.; Guoxue, L. Research on comprehensive integration process and recycling technologies of biogas slurry. Trans. Chin. Soc. Agric. Eng. 2016, 32, 207-212. [CrossRef]

22. Sandefur, H.N.; Asgharpour, M.; Mariott, J.; Gottberg, E.; Vaden, J.; Matlock, M.; Hestekin, J. Recovery of nutrients from swine wastewater using ultrafiltration: Applications for microalgae cultivation in photobioreactors. Ecol. Eng. 2016, 94, 75-81. [CrossRef]

23. Caide, Y. Studies on Treatment Performance of Different Membrane Combinations for Pig Manure Digested Slurry; Chinese Academy of Agricultural Sciences: Beijing, China, 2018.

24. Masse, L.; Massé, D.I.; Beaudette, V.; Muir, M. Size distribution and composition of particles in raw and anaerobically digested swine manure. Trans. ASAE 2005, 48, 1943-1949. [CrossRef]

25. Marcato, C.E.; Pinelli, E.; Pouech, P.; Winterton, P.; Guiresse, M. Particle size and metal distributions in anaerobically digested pig slurry. Bioresour. Technol. 2008, 99, 2340-2348. [CrossRef] [PubMed]

26. Tambone, F.; Orzi, V.; D'Imporzano, G.; Adani, F. Solid and liquid fractionation of digestate: Mass balance, chemical characterization, and agronomic and environmental value. Bioresour. Technol. 2017, 243, 1251-1256. [CrossRef]

27. Masse, L.; Mondor, M.; Talbot, G.; Deschênes, L.; Drolet, H.; Gagnon, N.; St-Germain, F.; Puig-Bargués, J. Fouling of Reverse Osmosis Membranes Processing Swine Wastewater Pretreated by Mechanical Separation and Aerobic Biofiltration. Sep. Sci. Technol. 2014, 49, 1298-1308. [CrossRef]

28. Jiang, S.; Li, Y.; Ladewig, B.P. A review of reverse osmosis membrane fouling and control strategies. Sci. Total Environ. 2017, 595, 567-583. [CrossRef]

29. Jhaveri, J.H.; Murthy, Z.V.P. A comprehensive review on anti-fouling nanocomposite membranes for pressure driven membrane separation processes. Desalination 2016, 379, 137-154. [CrossRef]

30. Zacharof, M.-P.; Lovitt, R.W. The filtration characteristics of anaerobic digester effluents employing cross flow ceramic membrane microfiltration for nutrient recovery. Desalination 2014, 341, 27-37. [CrossRef]

31. Pieters, J.G.; Neukermans, G.G.J.; Colanbeen, M. Farm-scale Membrane Filtration of Sow Slurry. J. Agric. Eng. Res. 1999, 73, 403-409. [CrossRef]

32. Waeger, F.; Delhaye, T.; Fuchs, W. The use of ceramic microfiltration and ultrafiltration membranes for particle removal from anaerobic digester effluents. Sep. Purif. Technol. 2010, 73, 271-278. [CrossRef]

33. Fugère, R.; Mameri, N.; Gallot, J.E.; Comeau, Y. Treatment of pig farm effluents by ultrafiltration. J. Membr. Sci. 2005, 255, 225-231. [CrossRef]

34. Zhan, Y.; Dong, H.; Yin, F.; Yue, C. The Combined Process of Paper Filtration and Ultrafiltration for the Pretreatment of the Biogas Slurry from Swine Manure. Int. J. Environ. Res. Public Health 2018, 15, 1894. [CrossRef] [PubMed]

35. Abuzaid, N.S.; Bukhari, A.A.; Al-Hamouz, Z.M. Ground water coagulation using soluble stainless steel electrodes. Adv. Environ. Res. 2002, 6, 325-333. [CrossRef]

36. Park, S.H.; Park, B.; Shon, H.K.; Kim, S. Modeling full-scale osmotic membrane bioreactor systems with high sludge retention and low salt concentration factor for wastewater reclamation. Bioresour. Technol. 2015, 190, 508-515. [CrossRef] [PubMed] 
37. Bella, G.D.; Trapani, D.D. A Brief Review on the Resistance-in-Series Model in Membrane Bioreactors (MBRs). Membranes 2019, 9, 24. [CrossRef]

38. Salud Camilleri-Rumbau, M.; Popovic, O.; Briceno, K.; Errico, M.; Sotoft, L.F.; Christensen, K.V.; Norddahl, B. Ultrafiltration of separated digestate by tubular membranes: Influence of feed pretreatment on hydraulic performance and heavy metals removal. J. Environ. Manag. 2019, 250, 109404. [CrossRef]

39. Fujioka, T.; Nghiem, L.D.; Khan, S.J.; McDonald, J.A.; Poussade, Y.; Drewes, J.E. Effects of feed solution characteristics on the rejection of N-nitrosamines by reverse osmosis membranes. J. Membr. Sci. 2012, 409, 66-74. [CrossRef]

40. Nghiem, L.D.; Coleman, P.J. NF/RO filtration of the hydrophobic ionogenic compound triclosan: Transport mechanisms and the influence of membrane fouling. Sep. Purif. Technol. 2008, 62, 709-716. [CrossRef]

41. Voutchkov, N. Chapter 9-Membrane Filtration. In Pretreatment for Reverse Osmosis Desalination; Voutchkov, N., Ed.; Elsevier: Amsterdam, The Netherlands, 2017; pp. 187-219. [CrossRef]

42. Camilleri-Rumbau, M.S.; Soler-Cabezas, J.L.; Christensen, K.V.; Norddahl, B.; Mendoza-Roca, J.A.; Vincent-Vela, M.C. Application of aquaporin-based forward osmosis membranes for processing of digestate liquid fractions. Chem. Eng. J. 2019, 371, 583-592. [CrossRef]

43. MEEC. Discharge Standard of Pollutants for Livestock and Poultry Breeding; GB 18596-2001; Ministry of Ecology and Environment of the People's Republic of China: Beijing, China, 2001.

44. MEEC. Standards for Irrigation Water Quality; GB 5084-2005; Ministry of Ecology and Environment of the People's Republic of China: Beijing, China, 2005.

45. Sui, Q.; Zhang, J.; Chen, M.; Tong, J.; Wang, R.; Wei, Y. Distribution of antibiotic resistance genes (ARGs) in anaerobic digestion and land application of swine wastewater. Environ. Pollut. 2016, 213, 751-759. [CrossRef] [PubMed]

46. Gros, M.; Marti, E.; Balcazar, J.L.; Boy-Roura, M.; Busquets, A.; Colon, J.; Sanchez-Melsio, A.; Lekunberri, I.; Borrego, C.M.; Ponsa, S.; et al. Fate of pharmaceuticals and antibiotic resistance genes in a full-scale on-farm livestock waste treatment plant. J. Hazard. Mater. 2019, 378, 120716. [CrossRef] [PubMed]

47. Shi, L.; Xie, S.; Hu, Z.; Wu, G.; Morrison, L.; Croot, P.; Hu, H.; Zhan, X. Nutrient recovery from pig manure digestate using electrodialysis reversal: Membrane fouling and feasibility of long-term operation. J. Membr. Sci. 2019, 573, 560-569. [CrossRef] 